\title{
Intellectual Agility Stimulation to Improve Organizational Performance
}

\author{
Sutrisno \\ PGRI University, Semarang, Central Java, Indonesia \\ sutrisnopgrismg@gmail.com
}

\begin{abstract}
This study aims to develop theoretical leadership and organization, which describes the dimensions of Intellectual Capital, Intellectual Property and Organizational Performance. Based on the substantive and strategic dimensions of generating new concepts, the theory of intellectual agility stimulation (intellectual property) becomes a stimulus for the leader's thinking in making decisions in the right time, condition and situation. This study employs in depth literature review from main source. Based on a complete and indepth literature review, the empirical model of research shows that sharing knowledge that includes donating, collecting will trigger an increase in Intellectual Agility Stimulus and Professional competence. As a result, it will improve the performance of organizations that are ready to face the industrial revolution 4.0.
\end{abstract}

\author{
Keywords \\ intellectual stimulation; \\ intellectual agility; \\ organizational \\ performance

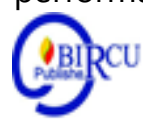

\section{Introduction}

Facing the industrial revolution 4.0, Indonesia is estimated to be a country with high potential. Meanwhile, with regard to the global competitiveness index at the 2017-2018 on World Economic Forum, it is still under other countries when compared to Malaysia, Singapore and Thailand, but Indonesia's position is quite calculated. This year, Thailand's global competitiveness index ranks 32, Malaysia 23, and Singapore third. Some of the reasons why Indonesia is still losing is due to the weakness of higher education and training, science and technology readiness, and innovation and business sophistication. The challenge for tertiary institutions to face the 4.0 revolution is to meet the need for quality lecturers and recruit the best college graduates to become lecturers.

It happens since in the era of the industrial revolution 4.0, the lecturer profession has become increasingly competitive. There are at least five qualifications and competencies of lecturers that are needed, including (1) educational competence, Internet of Thing-based competencies as basic skills; (2) competence in research, competence to build networks to foster knowledge, research direction, and skills to get international grants; (3) competence for technological commercialization, having the competence to bring groups and students to commercialization with technology on the results of innovation and research; (4) competence in globalization, a world without barriers, not stuttering towards various cultures, hybrid competence, namely global competence and excellence in solving national problems; and (5) competence in future strategies, where the world is easy to change and runs fast. Hence, they have the competence to predict exactly what will happen in the future and the strategy, by means of joint-lectures, joint-research, joint-publications, jointlabs, staff mobility and rotation, understanding the direction of SDG's and industry, and so on. The industrial revolution 4.0 requires a lecturer to be more competitive in developing and adapting to keep up with the times, the ability of lecturers can be achieved by applying stimulation of intellectual agility. 
Stimulation of intellectual agility becomes a theory that must be applied by lecturers in following the changes in revolution 4.0 to improve lecturer performance. It also builds individual lecturers and dares to take risks to increase knowledge following the changes in revolution 4.0 (collecting), as well as being able to innovate amidst his busy life as a lecturer whose main task is to teach and creatively solve problems arising from the impact of the 4.0 revolution (donating) either for himself and the campus that shelters him. In terms of agility, lecturers are required to continuously transform and experiment so that they can generate new learning ideas. Second, In terms of innovation, lecturers are required to have the capacity to translate their ideas or findings into valuable creativity. These innovations can be in the form of new products or services for student learning patterns, current learning processes, or innovations that produce new competitive advantages.

Darroch and McNaughton (2002) state that contributed knowledge aims to see individual knowledge into group and organizational knowledge over time, which in turn increases the knowledge stock available to firms. In contrast, Davenport and Prusak (1998) go one step further by repeating that knowledge assets are more difficult to imitate and imitate because of their intangibility and therefore more important than real resources. Moreover, Darroch and McNaughton's (2002) research is not easy to carry out in Davenport and Prusak's (1998) research because the knowledge contributed is intangibility (donating) which is difficult to imitate because each person's ability is different in acceptance (collecting), so it is necessary to look for special concepts for apply it.

Stimulation of intellectual agility (Stimulation of the leader in making decisions at the right time, conditions and situations) be an alternative theory to solve the above problems, Darroch and McNaughton (2002) and Davenport and Prusak (1998), in the end, increasing the performance of lecturers can improve the performance of universities in facing the 4.0 revolution.

\section{Review of Literatures}

\subsection{Intellectual Agility}

Resource based view theory is a theory of resources used by organizations in achieving sustainable competitive advantage based on organizational strategic resources. Resource based view theory states that organizations can achieve a sustainable competitive advantage strategy and gain superior advantages by owning or controlling strategic assets both tangible and intangible (Barney, 1991). According to the resource based view theory, it is important for an organization to build a group of valuable or valuable resources and tie them together in a unique and dynamic way to develop organizational success in achieving sustainable competitive advantage. Competitive advantage does not depend solely on the natural resource base, technology, or economies of scale as traditionally assumed, because they are easier to replicate. Conversely, competitive advantage according to resource-based theory is dependent on valuable, scarce, and difficult to imitate resources in an organization.(Penrose, 2009; Wright, Dunford, \& Snell, 2001). Resources that are valuable, scarce, and difficult to imitate are human capital in an organization (Wright et al, 2001).

Human Capital refers to the human aspect of the organization, namely the combination of skills, qualifications and expertise that gives individual character (Bontis et al., 1999). Bontis et al. (1999) further emphasizes the importance of human uniqueness to initiate, change and innovate in organizations through the motivational element, which shows the key to sustaining an organization in the long term. Human Capital represents the value of knowledge and talent included in the people who make up the organization, 
representing knowledge, capacities, knowledge, talents, competences, attitudes, intellectual agility, creativity, among others (IADE-CIC, 2003, Edvinsson and Malone, 1997, Bontis and Fitz-enz, 2002, Roos et al., 1997, Davenport et al., 2003, Kaplan and Norton, 1996, Santos-Rodrigues et al., 2011).

Currently, employee knowledge and skills are essential for any organization; However, several studies have proven that additional formation and knowledge creation do not necessarily lead to increased performance (Santos-Rodrigues et al., 2010). Sanchez et al. (2000) refer to employee training as a stepping stone to increasing the level of education of a company and consequently influencing innovation capacity. Character building is part of the national education system in National education regulation number 20 of 2003 which explains that education is a conscious effort instructurally creating a learning atmosphere and learning process so that students actively develop and explore themselves so that they have basic characters that relies on the religious power of self-control, personality, intelligence, noble character and social skills for him, of course this also focuses on the interests of the nation and state society (Pradana, 2020).

Managers must be tolerant of innovation mistakes, and must gradually develop relationships in a multidisciplinary context (Wan et al., 2005). Fear of making mistakes can cause the creative process to end; leaders must implement strategies and actions to encourage tolerance (Farson and Keyes, 2002). The supervisor also has great power to identify potential sources of innovation in the organization; This strength was identified by Nonaka and Takeuchi (1995) who argue that middle managers identify and combine knowledge to make it explicit. This gives managers / directors a commitment to the organization and their employees.

Maciocha and Kisielnicki (2011) argue that the importance of active employee participation in organizational decision making. As an emphasis on the important role of intellectual capital in creating company value. Furthermore, several studies have concluded that there is a positive and direct relationship between Human Capital and product innovation (Santos-Rodrigues et al., 2010) and that there is a positive and indirect relationship between Human Capital and management innovation (Santos-Rodrigues et al., 2012, Santos-Rodrigues et al., 2013, Costa, 2010).

\subsection{Transformational Leadership}

Bass (1996) states transformational leadership as a process that increases followers' awareness of consequences, influences subordinates to set aside personal interests for the sake of the organization, and makes subordinates work hard and earnestly. Transformational leadership can motivate others to do more than expected.

Antonakis, Avolio, and Sivasubramaniam (2003 )defines transformational leadership as a proactive leader, a leader who is able to increase follower awareness for the collective interest, and help followers achieve goals in an extraordinary way. SThe leader must have the ability to refine the ethics, beliefs, and requirements of followers into a vision, and then guide them in pursuing that vision. The leader's role must be present to convince and guide people until they reach their vision. And Followers are driven by their leader's behavior and they take advantage of the leader's role as a role model. The leader behaves in a very good way, shows confidence, and takes a position according to the followers' reasons to recognize a leader who has an understandable moral set and take steps as a role model for the group.

Inspirational motivation as proposed by Bass (1997) is the extent to which leaders express attractive dreams and stimulate followers. Leaders raise workers' awareness of the 
organization's mission and vision and give confidence to accept and commit to that vision, and this is a cutting edge fact of the transformational leadership style.

Intellectual stimulation as expressed by Bass (1997) is a leader in terms of challenges to rules, missions, and individuals who build, take risks, face assumptions, and promote follower thinking by providing a structure. Throughout the structure, followers will receive guidance on how to relate to the leader and goals. It also helps them identify ways to connect with the organization and with each other. The leader seeks ideas from the group and gives them confidence to contribute. Leaders teach followers to learn, and to be independent, everyone should be treated as an important contributor to the workplace. The leader will appear as a mentor, he must pay attention to every need of the contributor, and pay attention to the concerns and requirements of followers.

\subsection{Organizational Performance}

Organizational effectiveness has been one of the most researched issues since the beginning of organizational theory development (Rojas 2000). Although there is some consensus, there is still a lack of agreement regarding the definition and operationalization of this concept (Cameron 1986). Organizations determine, implement and adapt organizational strategies successfully. A performance measurement system that holds the strategy together by consistently evaluating the effectiveness of the strategy amid unpredictable external forces. Kaplan and Norton (2004: 10), state that organizational strategy describes how the company will create value for customers and stakeholders. Strategy is also a means by which long-term goals are achieved (David, 2003: 11). In essence, the strategy must define a set of activities / organizational performance that must be carried out to move the organization in the desired direction. Strategic organizational performance is the performance that the entire organization does, to achieve its goals and visions. Robbins (1987: 42) explains that wherever the strategy changes, the structure must follow and the structure usually must cover various aspects of the organization such as; company vision, mission, various departments or organizational functions, corporate culture and activities / organizational performance (David, 2003: 7-25).

Performance measurement describes information about the organization's past, present and expected position from the organization (Bititci et al., 2004: 28-30; Ritter, 2003: 44-48). The relationship between transformational leadership and organizational performance has been analyzed in the literature (Bass, Avolio, Jung, \& Berson, 2003; Howell \& Avolio, 1993). demonstrated a positive relationship between transformational leadership and organizational performance (DeGroot, Kiker \& Cross, 2000; Lowe, Kroeck, \& Sivasubramaniam, 1996; Patterson, Fuller, Hester \& Stringer, 1995). These results apply to different organizational contexts and different success criteria, for example (group) performance (Dvir, Eden, Avolio, \& Shamir, 2002; Pillai \& Williams, 2004), project success in the R\&D department (Keller, 1992), and innovation (Howell \& Higgins, 1990; Shin \& Zhou, 2003).

In a study in the US army, the relationship between transformational leadership and performance was partly mediated by the level of potential and unit cohesion analyzed (Bass et al., 2003). Tsai, Chen, and Cheng (2005) identified positive employee moods to mediate the relationship between transformational leadership and leadership success whereas the leader-follower-relationship was confirmed to be a mediator by Wang, Law, Hackett, Wang, \& Chen (2005). Bass (1985) identifies the components of transformational leadership: Idealized influence, Inspirational Motivation, Intellectual stimulation. Leaders stimulate followers by questioning assumptions, reframing problems, and approaching old situations in new ways. There is no public ridicule or criticism of follower errors (Bass \& Avolio, 1994). 


\subsection{Basic Theoretical Model}

Based on the study of Resources Based View (RBV) theory and comprehensive and in-depth leadership, it can be integrated, as shown in Figure 1.
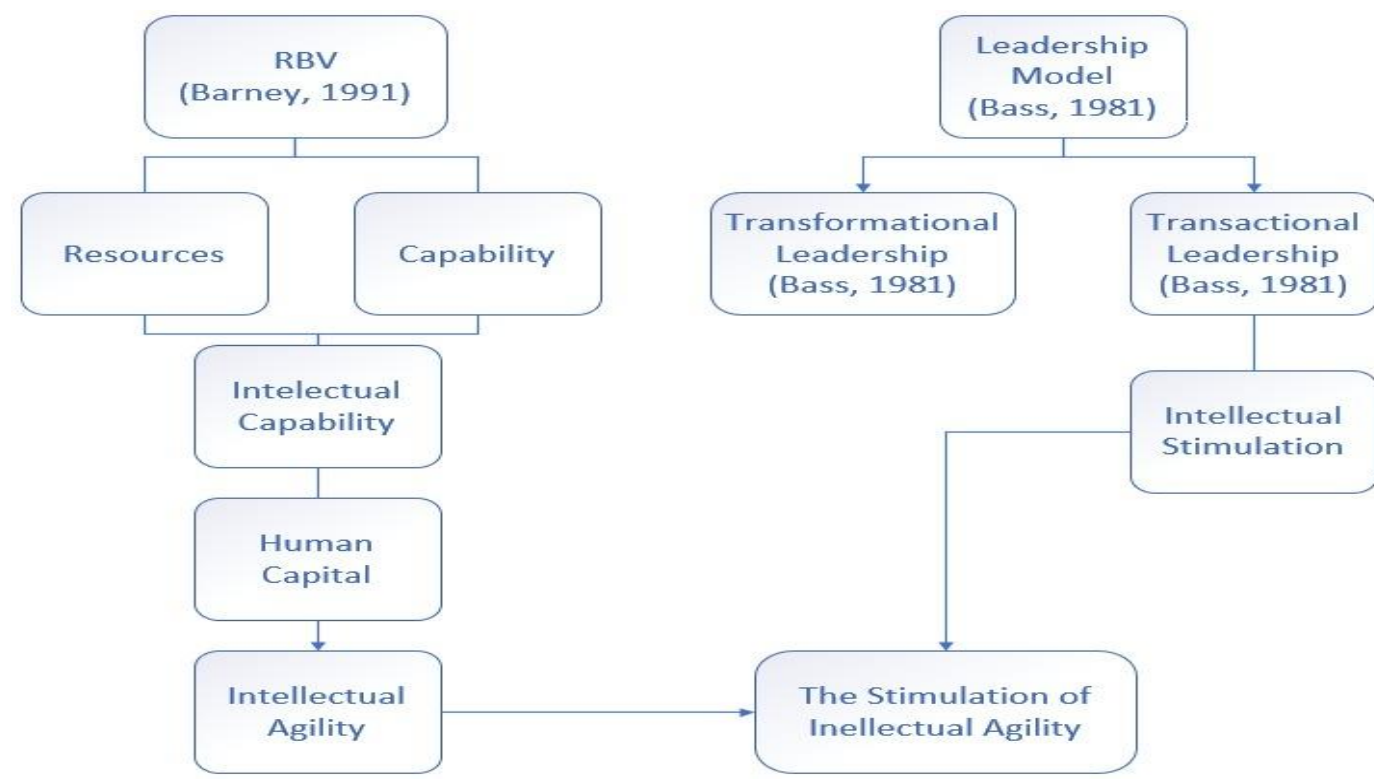

Figure 1. Integration of Resources Based View and Leadership

The intensity and eccentricity of comprehensive and systemic Knowlegde Sharing will result in the stimulation of intellectual agility. The stimulation of Intellectual Agility owned by the Organization will trigger Professional Competence, the consequence will increase the Organizational Performance.

\section{Research Methods}

This paper employs literature review as a methodology for conducting research. The data were taken from main source including recent articles and journals. The researcher synthesizes his result of reading and put the factual idea which support his argument to answer the research questions.

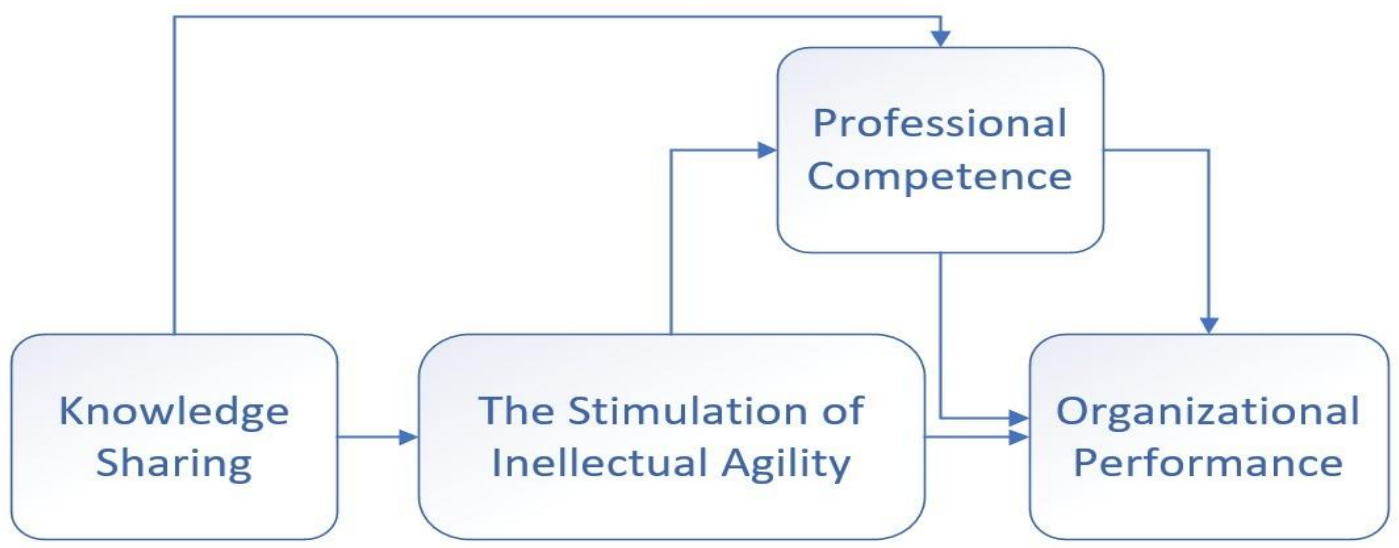

Figure 2. Basic Theorical Model of Intellectual Agility Stimulation 


\section{Results and Discussion}

\subsection{Knowlegde Sharing}

The process of exchanging knowledge and jointly creating new knowledge (de Vries et al., 2006), is recognized as a source of competitive advantage (Grant, 1996, Riege, 2005) and innovation (Collins and Smith, 2006, van Wijk et al., 2008). In order to share knowledge and the combination of knowledge to be effective, the contribution and gathering of knowledge is very important (de Vries et al., 2006). Thus, we differentiate between knowledge-donating (communicating knowledge to others) and accumulating knowledge [actively consulting others for their intellectual capital] (de Vries et al., 2006). The successful exchange of knowledge between donors and collectors is the fundamental means through which employees can contribute to the dissemination of knowledge, and, in turn, productivity and performance at the team and organizational level analysis. In particular, research reviewed by Wang and Noe (2010, p. 115) revealed a positive relationship between knowledge sharing and a combination of knowledge and important organizational outcomes, such as reduced production costs, faster completion of new product development projects, team performance, enterprise capabilities. innovation, and firm performance. Despite the obvious advantages associated with knowledge combinations and combinations, many organizations fail to exploit their competitive advantage to the fullest extent (Wang and Noe, 2010). Therefore, we need to increase our understanding of how organizational and interpersonal contexts influence knowledge sharing to increase the potential for organizations to compete more effectively.

Although there are several theories about leadership that can assist in enhancing our understanding of the knowledge sharing process, such as transformational leadership (Bass and Avolio, 1990, Gang et al., 2011) or ethical leadership (Brown et al., 2005) we investigate the quality of relationships. the exchange between the leader and its members, better known as the leader member exchange [LMX] (Gerstner and Day, 1997). Our rationale for applying the LMX theoretical lens is to allow us to investigate how the different relationships that vary in both quantity and quality affect the relationship betweendonation-based and knowledge-based knowledge accumulating. By focusing on the relationship between employees and managers as well as social exchange theory, we propose that the quality of the relationship is very important for knowledge combination and knowledge combination.

ELMX relationships, however, have a more market, transactional, and contractual character, and do not imply long-term or open and diffuse obligations between managers and employees (Kuvaas et al., 2012b). Conversely, exchanges are subject to downward influence, differences in formal status, and separate agreements, and they demand payment within a certain time period (Kuvaas et al., 2012b). Furthermore, employee motivation to contribute knowledge in ELMX relationships may play a greater role, and knowledge sharing is likely to be seen as extra role behavior that needs to be rewarded. This, in turn, should increase the instrumental motivation of managers to accumulate knowledge and result in more selective knowledge gathering.

\subsection{Knowledge Donating}

Darroch and McNaughton (2002) stated that contributed knowledge aims to see individual knowledge into group and organizational knowledge over time, which in turn increases the knowledge stock available to firms. Companies that promote employees to share knowledge in groups and organizations tend to generate new ideas and develop new business opportunities, thus facilitating innovation activities. 
Davenport and Prusak (1998) explain that knowledge assets are more difficult to replicate because of their intangibility and therefore more important than real resources. Knowledge sharing helps improve overall team effectiveness, to develop better and more accurate decisions (Prahalad \& Hamel, 1990; Zajac \& Bazerman, 1991). In the context of higher education, this academic institution is classified as a knowledge-based organization where knowledge functions as a core competency and is the basis for an institution's competitive advantage. An obvious example is the sharing of technical knowledge among academic staff in general or specifically enhancing the capacity and quality of research carried out by universities.

Contributing important knowledge is carried out by leaders both based on previous work experience and based on the experiences of others obtained because this is to anticipate changes in innovation from peasing, careful handling of internal and external skills, resources and competencies to keep the business running in a favorable environment. keep changing. (Teece et al 1997). Contributing knowledge requires awareness to share knowledge from someone voluntarily and there is an individual's intellectual agility to convey the knowledge they have because it is not certain that the knowledge they have can be accepted by others well, intellectual agility here is seen from a two-way perspective from the recipient and from the giver. From the recipient, intellectual agility intelligence,

\subsection{Knowledge Collecting}

Knowledge is one of the most valuable resources of modern times (Kommunale Gemeinschaftsstelle für Verwaltungs management, 2001; Moustaghfir \& Schiuma, 2013). The new information age and the shift towards a knowledge economy have made this resource increasingly important to organizational success (Jelenic, 2011). This can be a competitive advantage for individuals and companies facing today's global market challenges (Holsapple \& Joshi, 2002; Moustaghfir \& Schiuma).

Knowledge management is defined as the management of critical business knowledge. This organizational goal consists of various processes, including the development, organization, diffusion, and use of knowledge (David Skyrme Associates, 2011). According to Van Den Hooff and De Ridder (2004), sharing knowledge has two aspects; collect or receive, and share or contribute to, knowledge. They define contributed knowledge as "communication based on an individual's desire to transfer intellectual capital" and gathering knowledge as "trying to convince others to share what they know." These two distinct processes are active processes in the sense that a person engages in active communication with others for the purpose of transferring knowledge, or consults others to gain access to their intellectual capital.

Knowledge sharing can be defined as "the transfer of knowledge between individuals, groups, departments, and organizations" (Zhang \& Jiang, 2015, p. 1). Several authors categorize the sharing of knowledge into different processes, such as contributing knowledge and gathering knowledge (van den Hooff \& de Leeuw van Weenen, 2004). While knowledge contributor refers to the process of sharing one's knowledge with others, knowledge gathering refers to the process of asking others to share knowledge with themselves. It is very important to examine the process of contributing to knowledge. Therefore, the term 'knowledge sharing' is used to develop an effective knowledge management program that encourages knowledge sharing, this study aims to examine the current situation. 


\subsection{Professional Competence}

Van Den Hooff and De Ridder (2004) sharing knowledge has two aspects; collect or receive, and share or contribute to, knowledge. They define contributed knowledge as "communication based on an individual's desire to transfer intellectual capital" and gathering knowledge as "trying to convince others to share what they know." These two distinct processes are active processes in the sense that a person engages in active communication with others for the purpose of transferring knowledge, or consults others to gain access to their intellectual capital. Intellectual capital in relation to being a lecturer is the extent to which he has mastered the knowledge of his field professionally,

Competencies related to the skills of lecturers in the learning process are included in the category of professional competences. Professional competence is the mastery of broad and in-depth learning materials, including mastery of curriculum content and philosophical substance of scientific lessonsMaria Liakopoulou (2011) Meanwhile, Komara (Jamal: 2009: 157) states that professional competence is the ability to handle adjustment tasks and lecturer competence is very important because it is directly related to the performance shown.

The indicators used to measure the level of professional competence of lecturers include understanding the right curriculum teaching materials, understanding concepts and relationships with other sciences, and mastering the steps in research and critical analysis to explore teaching materials, skills, knowledge, attitudes, and motivational variables that form the basis for specific situations (see Epstein \& Hundert, 2002; Kane, 1992; Klieme, Hartig, \& Rauch, 2008). According to experience, these skills, knowledge, attitudes, and motivational characteristics are not innate, but can be learned and can easily be taught.

Teaching isn't just a cognitive challenge; also socially and emotionally demanding (Jennings \& Greenberg, 2009). To meet this challenge over a long period of time, lecturers need to manage to develop ways of coping with the constant demands of their work. Therefore, lecturers need to develop self-regulation skills to maintain their work commitments over time and to hinder unfavorable motivational and emotional outcomes.

Sharing knowledge at the organizational level: it is very important to achieve any innovation (Cao and Xiang, 2012; $\mathrm{Hu}$ and Randel, 2014). In general, knowledge contributes to the generation of creative thinking and ultimately innovates (Birasnav, 2014; Chen et al., 2014; Coombs and Hull, 1998; Evanschitzky et al., 2007; He et al., 2014; Nightingale, 1998; Rechberg and Syed, 2014) and flows between different levels of creativity (Nonaka, 1991; Vicari and Troilo, 2000). Understanding the relationship between knowledge sharing and organizational creativity is critical because interpersonal dynamics (such as teams, task forces, internal communities) are often the primary mechanisms essential for achieving innovation (Brown and Duguid, 1991; Chi et al., 2009; Chiaburu et al. , 2013; et al., 2014; Lin, 2010; West, 2002).

Spencer (1993) states that the relationship between competence and employee performance is very close. Likewise, other findings indicate that competence has a positive and significant effect on performance. Pedagogical competence is the ability of a techer related to the level of understanding of students, the learning process and selfactualization.Adnan Hakim(.2015) states that, pedagogic competence is the ability to manage student learning which includes student understanding, instructional design and implementation, evaluation of learning outcomes, and development of learners to actualize their potential. Competence is considered to have contributed directly to the success rate of lecturers in transferring their knowledge to their students.Kpedagogic, personal and social competences affect lecturer performance. 
In leadership, management transition plays a major role. Transitions are challenged and developed, as individuals in such situations encounter new situations that make existing leadership routines and behaviors inadequate. Transitions require the flexibility to learn new ways of dealing with unexpected problems and opportunities. Individuals who can't let go of old behavior patterns or who don't recognize nuances in different situations are likely to fail. Successful leaders thrive on the job (McCall, Lombardo, \& Morrison, 1988; Tannenbaum, 1997). They learn leadership from everyday experiences and go out of the day. Unfortunately, many leaders have slipped. Such leaders may rely too much on what made them into management in the first place and are likely to stop learning what it takes to perform effectively in new situations. A relatively recent construction, entitled intellectual agility, is increasingly recognized as essential to long-term leadership success (Lombardo \& Eichinger, 2000; Spreitzer, McCall, \& Mahoney, 1997).

Intellectual agility will likely be an important component of management practice in most organizations. Intellectual agility can be a key indicator of the success of future leadership. Furthermore, by paying attention to the intellectual agility of the various lecturers' capital made during their careers and discussing it. We then present measures of intellectual agility and review some of the empirical findings. To be able to read and understand changes in the environment requires sufficient experience and expertise in the field, with the professional competence of a lecturer being challenged by the changing times to face changes in the thinking style of his students because each has their own style and way of thinking.

Intellectual Capital (knowledge) is a critical force that is responsible for economic growth (Huang and Liu, 2005). In this globalization arena, modern business is mainly driven by intellectual capital and human capital helping organizations to build and maintain their competitive advantage (MacDougall and Hurst, 2005). Educated and wise people in organizations are responsible for creating wealth for their organizations and only machines will not do it (Garcya-Meca and Martinez, 2005). It has long been known that human capital is an important part of the wealth of organizations and countries (Cabrita and Bontis, 2008). It has been proven that there is a significant relationship between human capital, efficiency and financial performance (Maditinos et al., 2011). Knowledge measured as human capital has a significant effect on economic performance (Rafiei et al., 2011). Human capital or labor is the most intellectual asset in an organization (Hajiha and Hasanloo, 2011). In fact, human capital plays a major role in organizational performance (Ahmadi et al., 2011). It has been proven that human capital is the most important component of intellectual capital in influencing the organizational performance of pharmaceutical companies (Khalique et al., 2011). Ahangar (2011) states that human capital is more efficient than the other two types of capital (structural and physical) in terms of value creation and efficiency. Human capital is the most valuable component of intellectual capital and companies with greater human capital efficiency tend to have better financial performance (Sirinuch N, 2015). Several human capital indicators show a positive and statistically significant relationship with company performance (Seleim et al., 2007). The greatest goal of human capital is to educate employees and maximize the ability of knowledge, skills, and intangible experiences to create company value and improve performance (such as the study of Hsiung and Wang (2012). There is a positive relationship between human capital and knowledge creation (Ning et al. ., 2011) Human capital has an effect on organizational innovation according to Al-Dujaili (2012) Ghorbani et al., (2012) states that there is a significant relationship between human capital management and organization.There is a direct relationship between human capital and productivity, performance. 
Lecturers are one of the elements in the field of education that must play an active role and place their position as professional educators in accordance with the demands of the growing society. As an effort to create a professional lecturer, the government has made applicable regulations to become a lecturer. Lecturers as professionals. need to have pedagogic competence, personality competence, professional competence, social competence. The three competences of educators that have been mentioned will affect the performance of lecturers, but there are competencies that greatly affect the performance of lecturers, namely professional competencies. As stated by (Dauda A \& Mohammed A M ..(2012) stated that professional competence is very important, because it is directly related to the performance shown. Increasing the professional competence of lecturers in an effort to improve lecturer performance can also be done by increasing lecturers' work motivation. Lecturers teach because someone motivates them to work. This is in accordance with the opinion Bill Donaldson \& Frances Runciman (2010) stated that one of the factors that caused the low level of professionalism of lecturers was the lack of motivation of lecturers to improve their quality. Lecturers are expected to have the motivation to actualize themselves as educators who can become role models for students (Dauda A \& Mohammed AM, 2012). So that the work motivation of lecturers can improve the quality of learning education which in turn can improve higher education performance.

\section{Conclusion}

Based on the explanation above, it can be concluded that by knowlegde Sharing which includes Donating, Collecting will trigger an increase in Intellectual Agility Stimulus and Professional Competence, the consequence will increase Organizational Performance.

\section{References}

Adnan Hakim (.2015).Contribution of Competence Teacher (Pedagogical, Personality, Professional Competence and Social) On the Performance of Learning. The International Journal Of Engineering And Science (IJES) ISSN (e): 2319 - 1813 ISSN (p): 2319 - 1805

Alavi, M., \& Leidner, DE (2001). Knowledge Management and Knowledge Management Systems: Conceptual Foundations and Research Issues. MIS Quaterly, 25 (1), 107136.

Antonakis, J., Avolio, BJ, \& Sivasubramaniam, N. (2003). Context and leadership: an examination of the nine-factor full-range leadership theory using the Multifactor Leadership Questionnaire. The Leadership Quarterly, 14.

Ajzen, I. (1991). The Theory of Planned Behavior. Organizational Behavior and Human Decision Processes, 50 (2), 179-211.http://dx.doi.org/10.1016/0749-5978(91)90020$\mathrm{T}$

Ajzen, I., \& Madden, TJ (1986). Prediction of Goal-Directed Behavior: Attitudes, intentions, and perceived behavioral control. Journal of Experimental Social Psychology, 22 (5), 453-474.http://dx.doi.org/10.1016/0022-1031(86)90045-4

Al-Alawi, AI, Al-Marzooqi, NY, \& Mohammed, YF (2007). Organizational Culture and Knowledge Sharing: Critical success factors. Journal of Knowledge Management, 11 (2), 22-42.http://dx.doi.org/10.1108/13673270710738898 
Ardichvili, A., Page, V., \& Wentling, T. (2003). Motivation and Barriers to Participation in Virtual Knowledge-Sharing Communities of Practice. Journal of Knowledge Management, 7 (1), 64-77.http://dx.doi.org/10.1108/13673270310463626

Argote, L., Ingram, P., Levine, JM, \& Moreland, RL (2000). Knowledge Transfer in Organizations: Learning from the experience of others. Organizational Behavior and Human Decision Processes, 82 (1), 1-8.http://dx.doi.org/10.1006/obhd.2000.2883

Bakker, M., Leenders, RT, Gabbay, SS, Krstzer, J., \& Van Engelen, JML (2006). Is trust really social capital? Knowledge sharing in product development projects. The Learning Organization, 13 http://dx.doi.org/10.1108/09696470610705479

$13 \quad(6)$

594-605.

Balfour, DL, \& Wechsler, B. (1996). Organizational Commitment Antecedents and Outcomes in Public Organizations. Public Productivity \& Management Review, 19 (3), 256-277

Bandura, A (1982). Self-efficacy mechanism in human agency, American Psychologist 37 (1982) (2), pp. 122-147.

Barney, JB, \& Hansen, MH (1994). Trustworthiness as a Source of Competitive Advantage. Strategic Management Journal, 15 (Special Issue), 175190.http://dx.doi.org /10.1002/ smj.4250150912

Bass, BM (1996). A New Paradigm of Leadership: An Inquiry into Transformational Leadership. US Army Research Institute for the Behavioral and Social Sciences.

Becker, HS (1960). Notes on the Concept of Commitment. The American Journal of Sociology, 66 (1), 32-40.

Bill Donaldson \&Frances Runciman, 2010.Service quality in further education: An insight into management perceptions of service quality and those of the actual service provider, Journal of Marketing Management Pages 243-256 | Published online: 06 May 2010

Chiu, CM, Hsu, M.-H., \& Wang, ETG (2006). Understanding knowledge sharing in virtual communities: An integration of social Chow, WS, \& Chan, LS (2008). Social networks, social trust and shared goals in organizational knowledge sharing. Information \& Management, 45 (7), 458-465.

Dauda Abdulsalam \& Mohammed Abubakar Mawoli .2012. Motivation and Job Performance of Academic Staff of State Universities in Nigeria: The Case of Ibrahim Badamasi Babangida University, Lapai, Niger State. International Journal of Business and Management; ISSN 1833-3850 E-ISSN 1833-8119 Vol. 7, No. 14; 2012

Davenport, TH, and L. Prusak. 1998.Working Knowledge: How Organizations Manage What They Know. Boston, ma: Harvard Business School Press.

David V. Day, Robert G. Lord, 1988, Executive Leadership and Organizational Performance: Suggestions for a New Theory and Methodology, Journal of Management, ISSN: 0149-2063 Online ISSN: 1557-1211 Vol 14, Issue 3, 1988

Darroch, J. and McNaughton, R. (2002), "Examining the link between knowledge management practices and type of innovation", Journal of Intellectual Capital, Vol. 3 No. 3, pp. 210-22.

Donate, MJ, \& \& De Pablo, JDS 2014. The Role of Knowledge-Oriented Leadership in Knowledge Management Practices and Innovation, JourPa 'of Business Research, 68, pp. 360-370.

Edvinson, L. \& Malone, MS 1997.Intellectual Capital: Realizing Your Company's True value by Finding Its Hidden Brainpower. New York: Harper Business. 
Fapohunda M. Tinuke. 2015. Dimensions of University Academic Staff Performance Apraisal in Selected Public Universities in Nigeria. Journal of Global Economics, Management and Business Research. 3 (3): 139-147. Published: 25th May 2015

Huang, CJ, \& Liu, CJ (2005). Exploration for the relationship between innovation, IT and performance.Journal of Intellectual Capital, 6(2), 237-252.

Johnson, WL, Johnson, AM, \& Heimberg, F. (1999). A primary and second order compo nent analysis of the organizational identification questionnaire. Educational and Psychological Measurement, 59 (1), 159-170

Kaplan, Robert S. and David P Norton. (2004): Strategy Maps: Converting Intangible Assets into Tangible Outcomes, Boston, MA: Harvard Business School Publishing

Md. Faruk Abdullah. 2012. The role of Islam in human capital development: a juristic analysis. Humanomics Vol. 28 No. 1, 2012 pp. 64-75

Maciocha A., Kisielnicki J., "Kapital intellectual problemy pomiaru - studium na przykladzie Sektora telekomunikacji", Scientific Publications of Warsaw Univ. Of Technology, Warsaw 2007; b

Pradana, D.A., et al. (Nasionalism: Character Education Orientation in Learning Development. Budapest International Research and Critics Institute-Journal (BIRCIJournal). P. 4026-4034.

Rasula, J., Vuksic, VB, \& Štemberger, MI (2012). The Impact of Knowledge Management on Organizational Performance. Economic and Business Review, 14 (2), 147-168.

Santos, Monica Franco, Pilar Rivera and Mike Bourne. (2014) Performance Management in UK Higher Education Institutions: The Need for a Hybrid Approach. London: Leadership Foundation For Higher Education

Salih Yesil, Zumrut Hatice Sekkeli, Ozkan Dogan (2012) An Investigation into the Implications of Islamic Work Ethic (IWE) in the Workplace, Kahramanmaraş Sütçü İmam Üniversity, Kahramanmaraş, Turkey Journal of Economics and Behavioral Studies Vol. 4, No. 11, pp. 612-624, Nov 2012 (ISSN: 2220-6140)

Saunders, M. Lewis. P., and Thornhill, A. (2012). Research methods for business students. Harlow, England: Financial Times Prentice Hall.

Snell, SA, Youndt, MA, \& Wright, PM (1996). Establishing a framework for research in strategic human resource management merging resource theory and organizational learning. In M. Poole (Ed.), Human Resource Management Critical Perspective on Business and Management. London and New York: Routledge.

Staub, FC, \& Stern, E. (2002). The nature of teachers 'pedagogical content beliefs matters for students' achievement gains: Quasi-experimental evidence from elementary mathematics. Journal of educational psychology, 94 (2), 344.

Steers, RM (1977). Antecedents and Out- comes of Organizational Commitment. Administrative Science Quarterly, 22 (1), 46-56.

Sujan, H., Weitz, BA, \& Kumar, N. (1994). Learning Orientation, Working Smart and Effective Selling. Journal of Marketing, 58 (3).

Wang, H., Law, KS, Hackett, RD, Wang, D., \& Chen, ZX (2005). Leader-Member Exchange as a Mediator of the Relationship between Transformational Leadership and Followers' Performance and Organizational Citizenship Behavior. The Academy of Management Journal, 48 (3).

Widén-Wulff, G., \& Suomi, R. (2003). Building a Knowledge Sharing Company Evidence From the Finnish Insurance Industry. In Proceedings of the 36th Hawaii International Conference on System Sciences (HICSS'03). IEEE Computer Society. 
Woerkom, M. van, \& Sanders, K. (2010). The Romance of Learning from Disagreement. The Effect of Cohesiveness and Disagreement on Knowledge Sharing Behavior and Individual Performance Within Teams. J Bus Psychol, 25.

Wright, PM, Dunford, BB, \& Snell, SA (2001). Human resources and the resource based view of the firm. Journal of Management, 27 (6), 701721.

Yang, C., \& Chen, L.-C. (2007). Can organizational knowledge capabilities affect knowledge sharing behavior. Journal of Information Science, 33 (1).

Zhang, J., Faerman, SR, \& Cresswell, AM (2006). The Effect of Organizational / Techno logical Factors and the Nature of Knowledge on Knowledge Sharing. In Proceedings of the 39th Hawaii International Conference on System Sci 